\title{
Pemanfaatan Telur Ayam Sebagai Pengganti Darah dalam Pematangan Telur Nyamuk Aedes aegypti
}

\author{
Rumbiwati $^{1}$, Joko Trimuratno ${ }^{1}$ \\ ${ }^{1}$ Laboratorium Parasitologi Fakultas Kedokteran, Kesehatan Masyarakat dan Keperawatan \\ UGM, Jl. Farmako, Sekip, Yogyakarta, rumbiwati@gmail.com.
}

Sumbisi: 21 Oktober 2020; Penerimaan: 15 Desember 2020

\begin{abstract}
ABSTRAK
Proses pengembangan nyamuk di laboratorium, nyamuk betina memerlukan darah untuk membantu pematangan telurnya karena darah mempunyai sumber protein tinggi yang diperlukan dalam pematangan telur nyamuk. Di laboratorium parasitologi darah segar didapatkan dengan cara laboran menggigitkan tanggannya langsung ke nyamuk. Hal ini sangat beresiko jika nyamuk yang digigitkan pembawa virus. Penelitian ini, menggunakan nyamuk Aedes aegypti selama tiga turunan (FO.F1,F2,F3) dan mencoba menggantikan darah dengan telur ayam sebagai protein dalam membantu proses pematangan telur nyamuk dan analisa data dengan One Way ANOVA.

Hasil penelitian menunjukkan jumlah telur nyamuk yang menetas dengan pakan telur ayam F0 82,32\%, F1 77,62\%, F2 86,72\%, F3 82,98\%. Jumlah telur nyamuk yang menetas dengan pakan darah $F 087,34 \%$, F1 87,71\%, F2 90,39\%, F3 83,87\%. Hasil analisis One Way ANOVA menunjukkan $F$ hitung $>F$ tabel dapat disimpulkan bahwa tidak ada perbedaan bermakna antara telur nyamuk menetas yang diberi pakan telur ayam dengan telur nyamuk menetas yang diberi pakan darah

Kesimpulan dari penelitian ini adalah selama tiga kali turunan nyamuk dengan pakan telur ayam, jumlah telur yang dihasilkan maupun yang menetas lebih rendah dari nyamuk dengan pakan darah. Telur ayam bisa menjadi alternatif pengganti darah untuk mematangkan telur nyamuk Aedes aegypti dalam sekala laboratorium.
\end{abstract}

Kata kunci: Nyamuk Aedes aegypti, darah manusia, telur ayam

\section{PENDAHULUAN}

Proses pengembangan nyamuk di laboratorium seperti proses metamorfosis nyamuk pada umumnya, yaitu telur akan menetas menjadi larva, larva menjadi pupa dan pupa menjadi nyamuk dewasa.(Suyanto S,dkk, 2011). Telur nyamuk didapatkan kembali dengan cara nyamuk jantan dikawinkan dengan nyamuk betina, setelah itu nyamuk betina akan mengalami proses pematangan telur. (Depkes RI, 2010). Pada proses ini nyamuk betina memerlukan darah manusia untuk membantu pematangan telurnya karena darah manusia merupakan sumber protein tinggi yang sangat baik dan diperlukan dalam pematangan telur nyamuk. Telur nyamuk akan matang dan menetas berkisar 3 sampai 5 hari .(Soegeng, 2006).

Di laboratorium parasitologi FKKMK UGM untuk membantu proses pematangan telur diperlukan darah segar segar. Para tenaga laboran maupun peneliti harus merelakan tanggannya digigitkan ke nyamuk. Hal ini merupakan tindakan yang berbahaya karena selain melukai diri sendiri Tindakan ini juga beresiko jika suatu ketika nyamuk yang digigitkan tanpa disengaja adalah nyamuk pembawa virus. Selama ini tindakan seperti ini masih sering dilakukan karena dianggap tindakan yang cukup efektif dan 
mempunyai tingkat keberhasilan yang tinggi dalam membantu proses pematangan telur nyam.

Ada kesamaan kandungan protein dalam darah dan telur ayam yaitu albumin.

(Healthline.https://www.healthline.com/n utrition/boiled-egg-nutrition,2020). Pada penelitian ini peneliti mencoba mencari alternatif lain yaitu menggantikan darah dengan telur ayam sebagai protein dalam membantu proses pematangan telur nyamuk. Penelitian ini akan membandingkan jumlah telur nyamuk yang dihasilkan antara nyamuk yang dibantu pematangan telurnya dengan darah dan nyamuk yang dibantu pematangan telurnya dengan telur ayam.

\section{METODE PENELITIAN}

\section{Jenis Penelitian}

Penelitian ini merupakan penelitian diskriptif analitik yaitu membandingkan jumlah telur yang dihasilkan pada nyamuk dengan pakan telur dan nyamuk dengan pakan darah. Hasil penelitian dianalisa dengan One Way ANOVA. Peneltian ini dilakukan di Laboratorium Parasitologi Fakultas Kedokteran, Kesehatan Masyarakat dan Keperawatan Universitas Gadjah Mada.

\begin{abstract}
Alat
sangkar nyamuk, aspirator, botol kaca, mikroskop disecting, bak penetasan telur nyamuk, mikropipet, ovitrap (perangkap telur, kertas saring basah dalam gelas gelap). Bahan: nyamuk Aedes aegypti jantan dan betina, telur ayam, darah, kapas, larva food, pipet tetes, blue tip, gelas plastik $60 \mathrm{ml}$, air gula $10 \%$.
\end{abstract}

\section{Cara kerja}

Menyiapkan alat dan bahan; menyiapkan enam sangkar yang berisi masing-masing 25 ekor nyamuk betina dan 50 nyamuk jantan Aedes aegypti, menggunakan aspirator. Pada keenam sangkar diberikan air gula !0\% sebagai sumber makanan. Pada hari ke enam saat nyamuk siap mematangkan telurnya, tiga sangkar pertama sebagai kelompok perlakuan diberikan pakan telur ayam (dengan perbandingan 1 bagian telur ayam : 3 bagian air gula $10 \%$ ), dan tiga sangkar berikutnya sebagai kelompok pembanding diberikan pakan darah (melalui gigitan tangan).

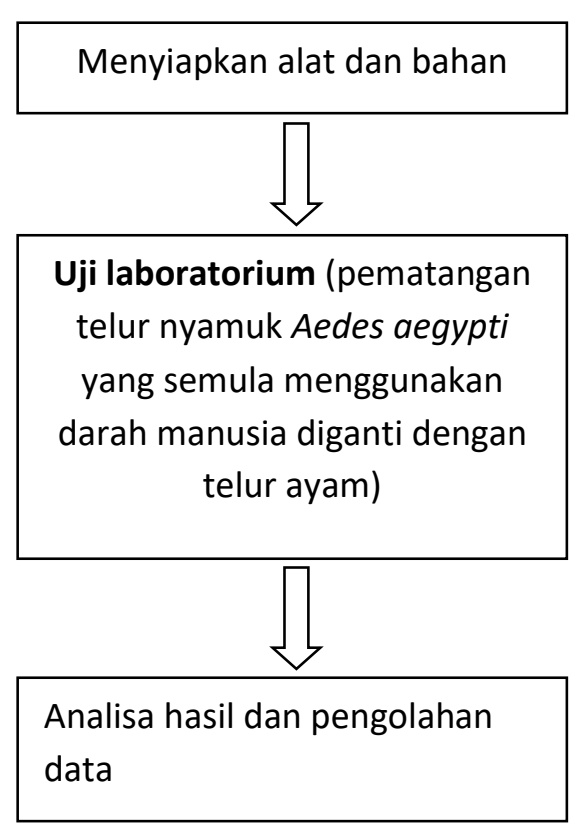

Gambar 1. Garis besar jalannya penelitian

Pada hari ke-delapan masingmasing sangkar diberi ovitrap dan ditunggu hingga nyamuk bertelur. Hari ke-tiga belas ovitrap diambil dan dikeringkan di suhu ruang. Jumlah telur nyamuk yang dihasilkan pada masingmasing sangkar dihitung dan dicatat dengan menggunakan mikroskop disecting. Semua telur yang didapat ditetaskan, dan dicatat jumlah larva yang menetas. Larva dipelihara sampai menjadi dewasa (nyamuk). Nyamuk ini adalah turunan pertama setelah perlakuan disebut F1. Sangkar nyamuk ditandai dengan kode F1. Turunan berikutnya (F2, F3), didapat dengan 
mengulangi proses $\mathrm{F} 1$. Pada penelitian ini hanya dilakukan sampai turunan nyamuk ke tiga (F3). Jumlah telur yang dihasilkan pada nyamuk dengan pakan telur ayam dibandingkan denngan nyamuk dengan pakan darah. Menghitung persentase telur yang menetas menjadi larva. Secara garis besar jalannya penelitian dapat dilihat pada skema Gambar 1.

\section{HASIL DAN PEMBAHASAN}

Pada penelitian ini jumlah telur yang dihasilkan pada nyamuk dengan pakan telur ayam dan nyamuk dengan pakan darah selama tiga kali turunan (F0, F1, F2, dan F3) ditunjukkan pada tabel 1.

Berdasarkan tabel 1. jumlah telur nyamuk yang dihasilkan dan menetas dengan pakan telur ayam dari tiga perlakuan menunjukkan rata-rata pada F0 252 dan menetas 208 (82,32\%), F1 296 dan menetas 230 (77,62\%), F2 326 dan menetas $283(86,72 \%)$, F3 491 dan menetas 408 (82,98\%). Jumlah telur nyamuk yang dihasilkan dan menetas dengan pakan darah dari tiga perlakuan menunjukkan rata-rata pada F0 739 dan menetas 679 (87,34\%), F1 906 dan menetas $794(87,71 \%)$, F2 950 dan menetas 858 (90,39\%), F3 1118 dan menetas 938 (83,87\%).

Tabel 1. Jumlah telur yang dihasilkan nyamuk dengan pakan telur ayam dan nyamuk dengan pakan darah.

\begin{tabular}{|c|c|c|c|c|c|c|}
\hline & $\begin{array}{l}\text { Telur yang } \\
\text { dihasilkan }\end{array}$ & $\begin{array}{c}\text { Telur } \\
\text { menetas }\end{array}$ & $\begin{array}{c}\text { Persentase } \\
\text { menetas }\end{array}$ & $\begin{array}{l}\text { Telur yang } \\
\text { dihasilkan }\end{array}$ & $\begin{array}{c}\text { Telur } \\
\text { menetas }\end{array}$ & $\begin{array}{c}\text { Persentase } \\
\text { menetas }\end{array}$ \\
\hline & & F0 & & & $\mathrm{F} 1$ & \\
\hline P 1 & 225 & 191 & 84,89 & 280 & 213 & 76,07 \\
\hline P 2 & 287 & 232 & 80,84 & 312 & 241 & 77,24 \\
\hline P 3 & 246 & 201 & 81,71 & 297 & 236 & 79,46 \\
\hline$\Sigma$ & 758 & 624 & 82,32 & 889 & 690 & 77,62 \\
\hline $\mathrm{R}$ & 252 & 208 & 82,32 & 296 & 230 & 77,62 \\
\hline K 1 & 750 & 632 & 84,27 & 925 & 814 & 88,00 \\
\hline K 2 & 708 & 666 & 94,07 & 901 & 793 & 88,01 \\
\hline K 3 & 761 & 640 & 84,10 & 892 & 777 & 87,11 \\
\hline$\Sigma$ & 2219 & 2038 & 87,34 & 2718 & 2384 & 87,71 \\
\hline \multirow[t]{2}{*}{$\mathrm{R}$} & 739 & 679 & 87,34 & 906 & 794 & 87,71 \\
\hline & & $\mathrm{F} 2$ & & & F3 & \\
\hline P 1 & 355 & 304 & 85,63 & 490 & 411 & 83,88 \\
\hline P 2 & 299 & 267 & 89,30 & 504 & 423 & 83,93 \\
\hline P 3 & 325 & 278 & 85,54 & 481 & 390 & 81,08 \\
\hline$\Sigma$ & 979 & 849 & 86,72 & 1475 & 1224 & 82,98 \\
\hline $\mathrm{R}$ & 326 & 283 & 86,72 & 491 & 408 & 82,98 \\
\hline K 1 & 981 & 893 & 91,03 & 1190 & 942 & 79,16 \\
\hline K 2 & 925 & 832 & 89,95 & 1108 & 931 & 84,03 \\
\hline K 3 & 944 & 851 & 90,15 & 1057 & 941 & 89,03 \\
\hline$\Sigma$ & 2850 & 2576 & 90,39 & 3355 & 2814 & 83,87 \\
\hline $\mathrm{R}$ & 950 & 858 & 90,39 & 1118 & 938 & 83,87 \\
\hline
\end{tabular}

Keterangan : $\mathrm{P}=$ nyamuk dengan pakan telur ayam, jantan 50 ekor dan betina 25 ekor

(Kelompok $\mathrm{P}$ ), $\mathrm{K}=$ nyamuk dengan pakan darah, jantan 50 ekor dan betina 25 ekor, $\mathrm{R}=$ Rerata (Kelompok K) 
Persentase telur yang menetas selanjutnya diuji statistic menggunakan One Way ANOVA. Hasil analisis menunjukkan $\mathrm{F}$ hitung $>\mathrm{F}$ tabel dapat disimpulkan bahwa tidak ada perbedaan bermakna antara telur nyamuk menetas yang diberi pakan telur ayam dengan telur nyamuk menetas yang diberi pakan darah

Pada penelitian ini selama tiga kali turunan (F0, F1, F2, dan F3) nyamuk dengan pakan telur ayam, baik jumlah telur yang dihasilkan maupun yang menetas lebih rendah dari pada nyamuk dengan pakan darah. Hal ini kemungkinan karena di dalam telur ayam maupun darah sama-sama mengandung albumin tetapi nyamuk Aedes aegypti lebih suka darah sebagai media untuk mematangkan telurnya. (Sayono, 2008). Telur ayam tetap bisa sebagai alternatif pengganti darah untuk mematangkan telur nyamuk Aedes aegypti dalam sekala laboratorium dilihat dari selama tiga kali turunan (F0, F1, F2, dan F3) nyamuk dengan pakan telur ayam tetap mau mematangkan telurnya hingga menetas. Hal ini kemungkinan karena ada kesamaan kandungan protein dalam darah dan telur. Protein dalam darah mengandung albumin, globulin dan fibrinogen. Kadar albumin normal dalam darah berkisar antara 3,5 hingga 5,9 gram per desiliter $(\mathrm{g} / \mathrm{dL})$. Protein dalam telur juga mengandung albumin. Kadar albumin paling banyak pada putih telur. Putih telur ayam ras mengandung 10,5 g protein/100 g putih telur dan 95\% diantaranya adalah albumin $(9,83 \mathrm{~g})$. (Healthline.https://www.healthline.com/n utrition/boiled-egg-nutrition,2020).

Kesamaan kandungan protein inilah kemungkinan telur bisa menggantikan darah dalam membantu proses pematangan telur nyamuk Aedes $s p$ dalam sekala uji laboratorium

\section{PENUTUP}

\section{Kesimpulan}

Berdasarkan hasil penelitian dapat disimpulkan sebagai berikut:

1. Jumlah telur nyamuk yang menetas dengan pakan telur ayam F0 $82,32 \%$, F1 $77,62 \%$, F2 $86,72 \%$, F3 82,98\%.

2. Jumlah telur nyamuk yang menetas dengan pakan darah F0 $87,34 \%$, F1 87,71\%, F2 90,39\%, F3 83,87\%.

3. Berdasarkan hasil uji statistik tidak ada perbedaan bermakna antara telur nyamuk menetas yang diberi pakan telur ayam dan telur nyamuk menetas dengan pakan darah

4. Telur ayam bisa menjadi alternatif pengganti darah untuk mematangkan telur nyamuk Aedes aegypti dalam sekala laboratorium.

\section{Saran}

Dapat dilakukan penelitian terkait dengan menggunakan bahan lain sebagai pengganti darah dalam mematangkan telur nyamuk Aedes aegypti sehingga didapatkan telur nyamuk menetas yang optimal.

\section{DAFTAR PUSTAKA}

Depkes RI, 2010, Pemberantasan Nyamuk Penular Demam Berdarah Dengue, Jakarta : Depkes RI.

Healthline.https://www.healthline.com/nu trition/boiled-egg-nutrition Diakses pada 6 Mei 2020

Sayono, 2008, Pengaruh Penerapan Lethal Ovitrap yang Dimodifikasi Terhadap Jumlah Nyamuk Aedes yang Terperangkap, Tesis : Universitas Dipenogoro

Soegeng, Soegijanto. 2006. Demam Berdarah

Dengue. 
Rumbiwati \& Joko Trimuratno/ Vol 3 (1) 2020, 1-5

Surabaya:Airlangga University press

Suyanto S, Darnoto, dan D. Astuti, 2011, Hubungan Pengetahuan dan sikap dengan praktek pengendalian nyamuk Aedes aegypti di Kelurahan Sangkrah Kecamatan Pasar Kliwon Kota Surakarta, Jurnal Kesehatamn, $4:$ 1-13 